\title{
Cashless Transaction in India
}

\author{
Shipra Gupta, Rupa Khanna
}

\begin{abstract}
It was the date of $8^{\text {th }}$ November, 2016 on which Rs. 500 and Rs.1000 bank notes of the Mahatma Gandhi series was demonetized. This news was announced by the government of India. This step was taken necessary to hold control on illegal activity and terrorism. After the demonetization Due to the lack of cash, digitalization has got the root. There is no way to do the payment. The Government of India has provided many cashless gadgets/devices to the public. Cashless transaction means when the goods and services are purchased by the use of various electronic mediums, without any use of cash and cheques. The aim of this study is to know about the modes of cashless payment, guidelines regarding its security, awareness programmes adopted by the government of India and its impact on both manners positive as well as negative.
\end{abstract}

Key Words: Cashless, Digital Payment, public awareness, online payment and mobile wallets etc.

\section{INTRODUCTION}

To make Faceless, Paperless, Cashless India, the Digital India is an extraordinary plan of the Government with a dream to renovate India into a digitally empowered culture and knowledge economy. Digital economy means a little or very low cash flow in a given society, thus every other purchases and transactions will be made by electronic channels, as direct debit, electronic funds transfer, mobile payments, multi-functional ATMs, internet banking etc. Cashless designating handled as by means of credit cards, bank transfers, and checks, with no bills or coins handed from person to person: some say we are headed toward a cashless society.

Cashless India includes the following.

1) Modes of Digital Payment

2) Security about digital payment

3) Capacity building and awareness

4) Awareness program to promote the digital payments within Government and People.

\section{1) Modes of Digital Payment}

i) Unstructured supplementary service data (USSD) it is a unique technology to global system for mobile communication (GSM). It depends upon the GSM network system. It provides mini statement, account balance and fund transfer information in mobile. This facility is available in 12 different languages and for poor people who cannot afford smart phones and for that place where low or no internet connectivity is available.

Revised Manuscript Received on August 10, 2019. Era Hill University, Dehradun, Uttrakhand, India. E-mail:

Rupa Khanna, Professor, Department of Commerce, Graphic Era Deemed to be University, Dehradun, Uttrakhand.
Shipra Gupta, Associate Professor, Department of Commerce, Graphic drshipragupta@rediffmail.com

ii) Aadhaar enabled payment system (AEPS) it can be used in all banking transactions. These transactions are done through a banking correspondent based on Aadhaar verification. If Aadhaar number is registered in that bank in which customer has held an account, there is no need any documentation, signature and physically presence of customer.

iii) Unified Payment Interface (UPI) If any customer has held a bank account, he/she can receive and sent payment through UPI-based application. It is a type of interoperable payment system.

iv) Digital wallets or mobile wallets It is a type of virtual wallet service, used by downloading an application. It stores bank account, debit/credit card information in that format which is encoded for the security of payment. Now at present some mobile wallets available in the market are freecharge, paytm etc. It can be used in add money in the mobile wallet and same can be used for make payments and purchases of goods and services.

v) Banks Pre-paid cards It is a type of instrument that can be used for load money for the payment of purchase the goods and services and may not be linked to the bank account of the customer. But in a debit card, issued by the bank it can be linked with the customer's bank account.

vi) Internet Banking It is the process of carrying out banking transactions by online. It is usually used to make payment or online fund transfer via NEFT, RTGS or IMPS. It has a wide scope.

vii) Mobile Banking It is the process of carrying out banking/financial transactions through a smart phone. The main function of this banking is to provide the information about different digital payment apps, a variety of mobile wallets and other services like UPI

viii) Micro ATM It is a device that is used for deliver basic banking services by many business correspondents. For conduct instant transactions, this device will fruitful for business correspondents. This is a low cost mobile phone connected device and can connect to across the country banks and available at every business correspondent. A person or customer can withdraw and deposit the money any time without gone the bank by the help of particular business correspondent after shown authenticated identity. A business correspondent provides the money to customer from his cash drawer. Essential business correspondent acts as a banker for his customer after verify the authencity of customers by using his UID. There are various functions of this device such as fund transfer, balance enquiry, deposit and withdrawal the fund.

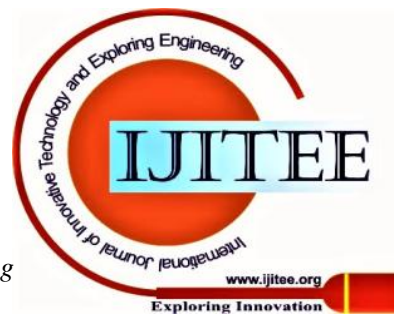




\section{Cashless Transaction in India}

ix) Banking cards This card is mostly used in digital payment method as due to its various features and benefits. Security of payment and its convenience is the main benefit of this card. Some well known card payment modes are Visa, Master card and Rupay.

x) PoS Terminals It is a hand held device that is basically cards (debit/credit cards). This is very beneficial for small level business owners, those who cannot afford expensive electronic devices.

xi) Bharat Interface for Money (BHIM) Application To make the payment in this app user allows to using the UPI application. It works as collaboration with Unified payment interface (UPI) and all the transactions are carried out by using a Virtual payment address (VPA). Bank account holder can easily link his/her account with this app. To link with multiple bank accounts, is also possible through this app. Anyone who has a mobile number, Valid bank account number and debit card, can access this app.

\section{2) Security About Digital Payments}

After digitalization it's mandatory how to know about the proper use of cashless transactions. . If we want that our country will be digitalized, proper cyber security need to be maintained by the government urban as well as in rural areas. Proper training and guidance should be given to those people who have unaware the knowledge of how to do digital payments. Everyone would want to know if the digital payments are secured or not and how we secured it. What are the precautions we have to make the secured transactions and what are the programmes arranged by government for the security of digital payments. Through Digital payment is a safe and secure method of transaction; recently PM Narendra Modi launched the app BHIM which is an online money transfer application. This app has a three-tier security system for the purpose of security. Its three-tier security is:

a. Only account holder can access his/her account.

b. It is registered through his/her mobile phone so he/she can manage app on his/her device.

c. If in any case someone fraud has acquired the information regarding account holder's documents for that the third and final tier is the 4 digit pass code. So, first the pass code is entered in order to access the application.

\section{Government should adopt these Awareness} programmers regarding cyber security.

i. Government should be taken a legal action regarding the awareness of safe and secured digital payment programme and minimum one person in a family should be awared about this online payment programme.

ii. To understand these programmes effectively government has to take effective advertisements and aware about the benefits from online transactions.

iii. Government has to opt multilayer security programme and OTP's for getting the faith and secured transactions.

3) Capacity Building And Awareness installed at all purchasing stores. It accepts all banking

It is an approach to develop the greater ability in people and organizations to address new challenges. It is an ability to perform how appropriate work can do either by individual or combined with others public sector organizations. It can be done either by provide simple training or by technical assistance and gain the knowledge and experience so that they can solve the problems by effective actions, reach sustainability and implement the changes. It can be used in several areas in organizational fields like: to make the strategic policies, planning and procedures and how these can be changed and controlled. Some policy, schemes and procedure programs are promoted by some institutions or organizations are as follows:

a. DigiShala - Educational TV Channel for Digital Payments on DD Free Dish.

b. Digital Finance for Rural India: Creating Awareness and Access through Common Service Centres (CSCs).

c. Vittiya Saksharta Abhiyan (Visaka) by Ministry of Human Resource Development (MHRD).

d. Indian Railways to install 10,000 Point of Sale (POS) machines to promote cashless transactions using debit/credit cards. State Bank of India has been mandated to install 10,000 POS machines at various locations.

\section{4) Promoting Digital Payments Within Government}

Government of India has doing many efforts for bringing paperless services across the country especially in rural areas. MeitY (Ministry of Electronics and Information Technology) is an e-governance program of the government of India. It provides a time bound and targeted approach to all citizen, businesses, and governments for assessing many services like receipts and payments through electronic modes. The guidelines of electronic payment and receipt system provide to all the departments so that they can help or educate to everyone.

\section{5) Promoting Digital Payments Among People}

Many services access by government for promoting cashless payments and many gadgets are develop by government for public interest. Many devices and incentives are provided by government.

a. Excise duty will be nil for POS (payment of sale) devices and all related goods for its manufactures.

b. By the use of debit/credit cards, e-wallets, mobile banking, different applications through mobile and different package of incentives and points are provided for the promotion of digital payment.

c. None of the charges are levied by banks and PPI (prepaid payment instrument) on customers for the transactions upto Rs. 1000 made by IMPS (immediate payment service), USSD based (unstructured supplementary service data), UPI (unified payment interface) system.

d. Different deductions promoted by this plan regarding Income tax and card payment system. 
e. Oil marketing companies for example LPG is provided some discount on per refill cylinder by online booking and online payment.

f. Different digital payment schemes, toll free helpline numbers and promotional digital payment schemes are run by Government of India.

g. No set up fees.

h. Low or minimum service charges will be charged on digital transactions.

Digital payment is very beneficial, if some points (guidelines) should be noticed by using it:

i) Digitalization is a step towards anti-corruption, which occurs during large money transaction.

ii) By the help of cashless transactions no cash in hand money is need there is no need for physical money.

iii) It works as Fast, Convenient and can be use as a proof.

iv) Reduce the corruption and documentation work, time saving, control on black money and easily access.

v) In rural areas where lack of net connectivity is a major problem, digital payment plays a major role.

vi) Most of the people they don't have mobile phones and bank accounts in rural areas, can use digital payment.

vii) From time to time many rewards, discounts and cash back offer provide to customers for using mobile wallets and digital payment apps.

viii) By paying the different types of bills from at home or anywhere.

ix) Scams can be avoided.

x) No need to go to banks and retained the currency.

xi) No one can deny to accept and payment.

xii) It's not possibility to fake currency.

xiii) Printing notes problem can be solved by using plastic cards.

xiv) Easily handle the money.

$\mathrm{xv)}$ It can also be used in emergency service.

xvi) No chances of currency duplicity.

xvii) These transactions are highly reliable.

Limitations: The limitations of cashless transactions are as below

i) Some people in India, they don't know cash less system, how to operate ATMs, smart phones transactions, etc. They feared about operate online money transactions.

ii) Poor internet connectivity.

iii) One of the major challenges for digital payment is the hardware security. Hackers have stolen the password through the android phones, ATMs and captured the finger prints, and misuse it by your accounts.

iv) Some people in India, they don't know the ads are not always true and secure. They believe on fake emails, ads and messages therefore they can easily deceive by such hackers.

v) Always do the help of someone is not beneficial for us regarding to help in learn the process of digital payment or online transactions. Sometime our innocence creates problems for us.

vi) Lack of proper security system.

\section{SUGGESTIONS}

i) From time to time new features (applications) should be developed in Software Company to know about the hackers and mistakes.

ii) Though a small initiative of going cashless can be taken in the urban areas where it is feasible. Whereas it raises the concern in rural areas. To achieve the same in a rural area a proper organization has to be setup to help the people in villages.

iii) After using the smart cards etc. their service charges should be lesser (minimum).

iv) Different incentives and schemes should be provided by the government for promote the digital transactions.

v) Everyone who is using digital banking applications should improve and upgrade their security level from time to time and should be very alert about digital security.

\section{CONCLUSION}

If everyone will operate the transactions by online manner, no one can corrupt the data. The government will be easily tracking to all the account holders' and catch the hacker's easily. Government has to take legal action seriously in this matter so that in each and every family minimum one person should be aware or learnt about how to do cashless transactions for digital payment and how to make a secure online transaction. However now we are not totally but mostly used this e-wallets and digital banking. Government has maintained many policies, awareness programs and schemes for upcoming this process in regular manner. So in upcoming years we can expect for secure and fully digitalized India. Slowly- slowly it has gain the popularity in India. Many apps are launched in this sector and many are in process. It will become a hassle-free and secure payment system in coming time.

\section{REFERENCES}

1. M.C. Baro, IJCRT, vol. 5(4) 2017 Digital India: Concepts and Implications. ISSN - 2320-2882.

2. Rani Suman (2016) Digital India: Unlessing Prosperity, Indian Journal of Applied Research, Vol 6(4) 187-189.

3. Gupta Neeru \& Arora Kirandeep (2015), Digital India: A Road map for the development of rural India, International Journal of Business management 2(2) 1333-42.

4. Jyoti Sharma, Research in Humanities \& Social Sciences, Digita India and its impact on the society 4(4) 2016.

5. Giridhari, Mohanta, S.S.Debashish \& S.K.Nanda, A Study on growth and prospects of digital India Compaign, Saudi Journal of Business and Management studies, Vol 1(2), 727-731, 2017. 